\title{
Human factors in emerging infectious diseases
}

Scott B. Halstead ${ }^{1}$

$$
\text { العوامل البئرية في الأهراض المعلية المستجدة }
$$

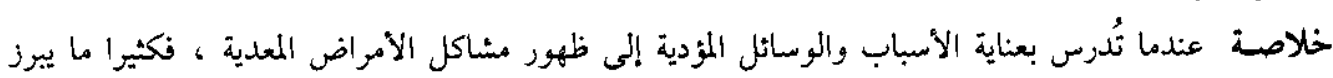

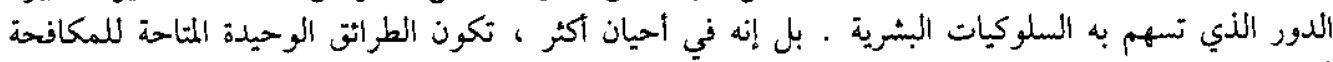

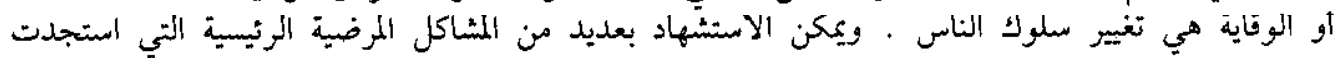

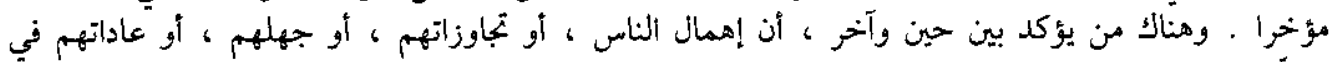

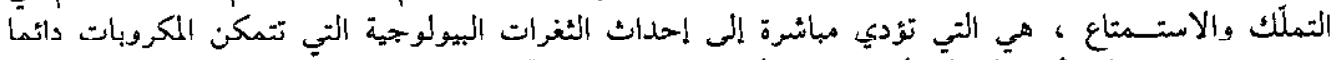

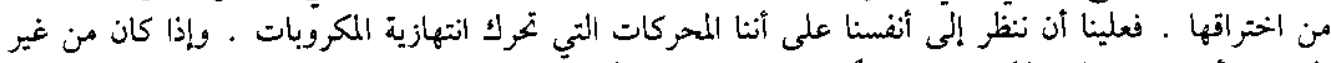

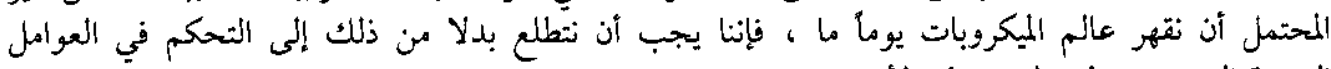

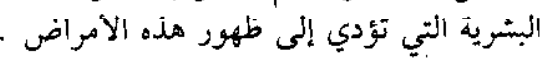

ABSTRACT When the underlying causes and mechanisms of emerging infectious disease problems are studied carefully, human behaviour is often involved. Even more often, the only methods of control or prevention available are to change human behaviour. Several major recent emerging disease problems can be cited. It is sometimes emphasized that it is human carelessness, human excesses, liuman ignorance or human habits of conquest or lejoure which contribute directly to the biological niches that microorganisms are all too capable of exploiting. We must look at ourselves as the engines of microbial opportunism. It is not likely that we will ever conquer tho miorobial world; wo must look instead to contral the human factors that contribute to emergence.

Les facteurs humains dans les maladies infectieuses émergentes

RESUME Lorsqu'on examine minutieusement les causes profondes et mécanismes des problèmes que représentent les maladies infectieuses émergentes, on constate que le comportement humain est souvent impliqué. Et plus souvent encore, les seules méthodes de prévention ou de lutte disponibles consistent à modifter le comportement humain. On peut citer plusieurs grands problèmes récents de maladies infectieuses émergentes. On souligne quelquefois que ce sont la négligence, les excès, l'ignorance de l'être humain ou encore les pratiques humaines de conquête ou habitudes de loisirs qui contribuent directement aux failles biologiques que les micro-organismes ne sont que bien trop capables d'exploiter. Nous devons nous considérer comme les instruments de l'opportunisme des microbes. Il est peu probable que nous puissions un jour conquérir le monde microbien; il nous faut donc plutôt agir sur les facteurs humains qui contribuent à l'émergence.

'Scientific Director, Infectious Diseases, Naval Medical Research and Development Command, 8.901 Wisconsin Avenue. Bethesda. MD 20889-5605, USA.

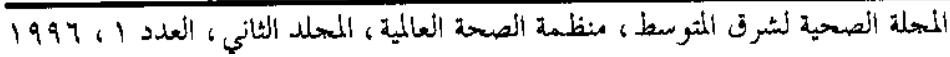




\section{Introduction}

It is conventional to analyse the phenomenon of emergence of disease from the perspective of the parasite-large and small - focusing on its ability to adapt to the human host. In this view, because of their extremely rapid reproduction rate, microorganisms have an advantage over the immune defences of generationally slower humans. Rapid reproduction rates foster mutations and the selection of successful variants, which quickly become the dominant population. When contending with old, established hosts, microorganisms use such mechanisms as immunosuppression or molecular mimicry to survive against human immune defences.

A surprisingly large fraction of all parasites that are regarded as "emergent" could also be called inadvertent or "careless" pathogens. These find their way into or onto humans, but have no escape mechanism. From the perspective of the parasite the human being is a "dead-end host". Examples include the virus that causes hantavirus pulmonary syndrome and Borrelia, which causes Lyme disease.

This paper will not discuss parasitism from the perspective of the parasite but explore the contributions that humans make to successful or inadvertent parasitism. It is essential to understand these factors because human behaviour is often the decisive determinant of emergence; further, a change in human behaviour can be the single most powerful defence out species has against the phenomenon of infectious disease emergence.

For many diseases the defence mounted in our heads is more powerful than the defence mounted in our lymph nodes or spleens.

\section{Enhanced encounters}

\section{Excess fertility}

Human behaviour contributes to emergence, first and foremost by enhancing the opportunity for parasites to encounter human beings. A very long list of behaviour patterns contributes to enhanced microbial encounters. The one with the most serious longterm consequences is excess human fertility (Table 1). It is a well established phenomenon in biology that, as the population density of a single species of animal or plant increases, the chances increase that a successful and often devastating pathogen will appear. As the human race marches towards a population of 10-12 billion in the next 30 years, there is a proportionate increase in the chances of devastating epidemics. The mechanism of unexpected epidemics is thought to be largely the result of increased

Table 1 Human factors in the emerdence of infectious diseases

A.

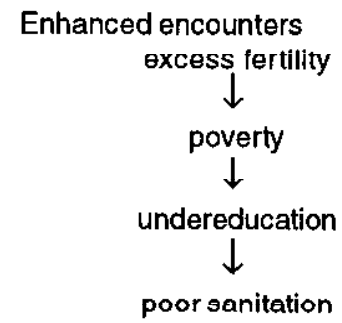

B. Tool making (technology)

- transportation

- mass production

- mass marketing

- communication

C. Changing ecology

- greenhouse gases

- pollutants

- fashions

- conflict 


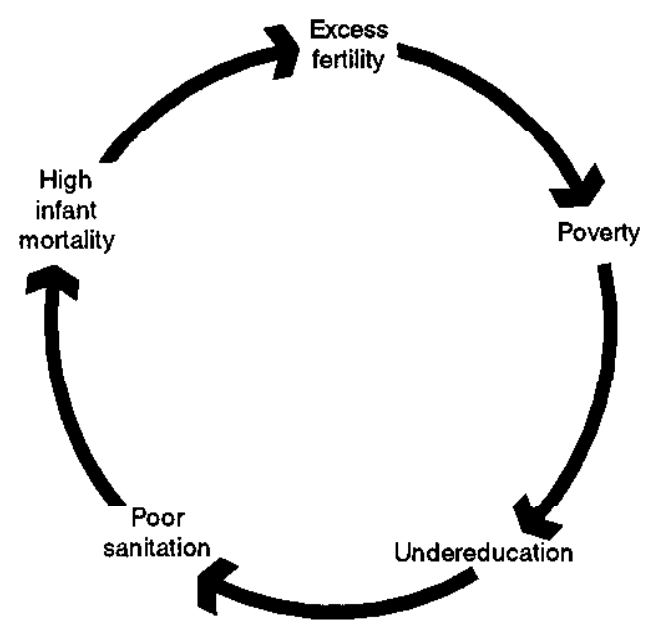

Figure 1 Cycle of underdevelopment

rates of parasite transmission, and this is because of the frequency of close contacts. Obvious examples are diseases caused by those organisms that infect body surfaces, such as skin (impetigo), mucosa (sexually transmitted diseases), gastrointestinal tract (diarrhoea) or respiratory tract (influenza, common cold. childhood diseases). Excess fertility often strains economic resources, generates poverty and contributes to the cycle of underdevelopment (Figure 1). Poverty contributes directly to low education and poor sanitation, which, in turn, lead to the promiscuous distribution of human and animal waste. In the past, faecal waste has probably been the greatest single contributor to successful parasitism.

Poor education, unsanitary conditions, high rates of disease and excess fertility form a powerful and sustaining positive feedback loop that fosters more and more of the same four phenomena (Figure 1). It may be concluded that the most important root cause of emerging infectious diseases is excess fertility.

\section{Tool-making technology}

Microbial encounters are also directly impacted by that other unique attribute of Homo sapiens, tool-making. Or, as it is recognized today, technology.

\section{Transportation}

The invention of the internal combustion engine and the vast oil industry that fuels all of modern civilization have created an evolutionally unprecedented industry. For work or pleasure, millions of people are moved short and long distances around the globe. In all likelihood, in the space of a few months, all but a few hundred million of the earth's population gain access to markets, visit relatives or tour about all in conveyances powered by internal combustion engines. This is an enormously powerful mechanism for enhancing microbial encounters (Table 1 ). Think of HIV/AIDS spreading along the trucking routes out of central Africa or of cholera. which jumped by ship from Bangladesh to Peru.

Technology plus excess fertility also contrive to help humans invade new hahitats. Homesteading, cattle ranching, timbering and gold mining in the tropical rain forests in Asia. Africa and south America provide many opportunities for inadvertent parasitism and for cross-species adaptation. While the precise events are not fully known, it seems probable that the encroachment of humans on jungle habitats has led to the cross-species infection of humans with simian retroviruses now known as HIV-1 and HIV-2 as well as being responsible for the recent Ehola virus outbreaks.

\section{Mass production}

Technolngy also makes possible the manufacture of industrial products that can harbour or nurture parasites or introduce them to humans in novel ways. For example, the

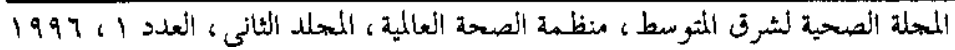


invention and distribution of ultra-absorbent vaginal tampons, which were found to shield Staphylococcus aureus, allowing the production and release of toxins and thus causing toxic shock syndrome.

\section{Mass marketing}

Technology also permits the distribution of processed foodstuff and fresh fruit and vegetables over a vast geographic area. If such food is contaminated, it could affect people far from the source of production. For example, there was a public health scare a few years ago in the United States when some grapes from Chile, which distributes food all over the western hemisphere, were apparently found to contain poison. Another example of this phenomenon is the salmonella outbreaks in the USA that resulted from contamination at a single mid-western ice cream production and filling facility.

\section{Communications}

Technology is also reflected in modern communications. Modern communications systems provide an unparalleled opportunity to "get into human heads" and influence human behaviour. Communications are the engine for mass markets and generate, for instance, fashions and fads or the desire to travel. In other words, the close encounters that occur because of modern transportation are motivated by modern communications.

\section{Changing ecology}

\section{Greenhouse gases}

The ecology of the earth is changing as a result of modern technology. The forces involved are huge and complicated and are poorly understood. The release of greenhouse gases on a large scale as byproducts of industrial processes, with the resultant global warming. is expected to lead to the exuberant growth of plants and algae as well as massive changes in climate. Each of these may affect the distribution of microorganisms, their pathogenic range, their virulence and their ability to become inadvertent parasites.

\section{Pollution}

Pollutants such as chlorofluorocarbons (CFCs) cause ozone depletion, which threatens people by allowing increased exposure to ultraviolet rays. It is also possible that increased concentrations of ultraviolet light may help to select or mutate microorganisms, a hypothesis that has not been fully studied.

\section{Conflict}

Finally, there is that most devastating fashion of them all, warfare. We are only several generations away from the largest such conflagration in history-the Second World War. Chemical and biological weapons, land mines, bombing and scorched earth policies - these have resulted, among other horrors, in vast armies of refugees, instant squalor and unspeakably unsanitary conditions. The same ecological disasters continue on a smaller scale day after day at multiple sites around the globe, leading to disturbances of habits and to the unsanitary conditions that contribute to enhanced $\mathrm{mi}$ crobial encounters and lead to increased chances of cross-species or inadvertent parasitism.

\section{Specific emerging diseases}

To illustrate the principles articulated above, the etiology, proximal cause, transmission mechanism and control methods are listed for 10 major emerging disease problems and these examined for the role of human factors (Table 2). 
Table 2 Selected emerging disease problems

\begin{tabular}{|c|c|c|c|c|}
\hline Disease & Etiology & Proximal cause & Mechanism & Control \\
\hline AlDS & HIV-1 & Sexual promiscuity & $\begin{array}{l}\text { Adaptation from } \\
\text { monkeys to man }\end{array}$ & $\begin{array}{l}\text { Change in } \\
\text { sexual behaviour }\end{array}$ \\
\hline $\begin{array}{l}\text { Hantavirus } \\
\text { pulmonary } \\
\text { syndrome }\end{array}$ & $\begin{array}{l}\text { Sin nombre } \\
\text { virus }\end{array}$ & $\begin{array}{l}\text { Increased } \\
\text { rodent population }\end{array}$ & $\begin{array}{l}\text { Weather } \\
\text { changes }\end{array}$ & $\begin{array}{l}\text { Increased } \\
\text { surveillance }\end{array}$ \\
\hline Cholera, Peru & Cholera EITor & Contaminated water & No chlorination & $\begin{array}{l}\text { Enforced } \\
\text { chlorination }\end{array}$ \\
\hline $\begin{array}{l}\text { Cholera, } \\
\text { South Asia }\end{array}$ & Cholera 0139 & Contaminated water & $\begin{array}{l}\text { Drinking } \\
\text { ground water }\end{array}$ & $\begin{array}{l}\text { Boil water, } \\
\text { use latrine }\end{array}$ \\
\hline Bloody diarrhoea & E. coliO157:H7 & Contaminated water & Mass marketing & $\begin{array}{l}\text { Strengthened } \\
\text { meat inspection }\end{array}$ \\
\hline $\begin{array}{l}\text { Haemornhagic } \\
\text { fever }\end{array}$ & Ebola virus & Close contact & No barrier nursing & Barrier nursing \\
\hline $\begin{array}{l}\text { Haemorrhagic } \\
\text { fever }\end{array}$ & Dengue virus & Mosquito bite & $\begin{array}{l}\text { Mosquitos breeding } \\
\text { in man-made } \\
\text { containers }\end{array}$ & $\begin{array}{l}\text { Reduce mosquito } \\
\text { breeding }\end{array}$ \\
\hline $\begin{array}{l}\text { Yellow fever } \\
\text { Peru }\end{array}$ & $\begin{array}{l}\text { Yellow fever } \\
\text { virus }\end{array}$ & $\begin{array}{l}\text { Bite of jungle } \\
\text { mosquito }\end{array}$ & $\begin{array}{l}\text { Expanding coffee } \\
\text { plantations }\end{array}$ & Vaccination \\
\hline $\begin{array}{l}\text { Haemorhagic } \\
\text { fever }\end{array}$ & $\begin{array}{l}\text { Rift valley } \\
\text { fever virus }\end{array}$ & Insect bite & $\begin{array}{l}\text { Change in } \\
\text { weather }\end{array}$ & $\begin{array}{l}\text { Increased } \\
\text { surveillance }\end{array}$ \\
\hline Drug resistance & $\begin{array}{l}\text { Malaria, } \\
\text { tuberculosis }\end{array}$ & Vector, contacts & Lax drug laws & $\begin{array}{l}\text { Decrease non- } \\
\text { prescription sales }\end{array}$ \\
\hline Lymo disonso & Barrolfa & Nymph hite & $\begin{array}{l}\text { Increase in deer } \\
\text { population, }\end{array}$ & $\begin{array}{l}\text { Decreased deer } \\
\text { population }\end{array}$ \\
\hline $\begin{array}{l}\text { Toxic shock } \\
\text { syndrome }\end{array}$ & $\begin{array}{l}\text { Staphylococcus } \\
\text { aureus }\end{array}$ & Tampon use & "Super" tampons & $\begin{array}{l}\text { Change in } \\
\text { regulations }\end{array}$ \\
\hline
\end{tabular}

\section{HIV/AIDS}

There can be no doubt that the emergence of HIV/AIDS has been assisted by human behaviour. Genetic studies provide uncontested evidence that HIV-1 is of simian origin. It is not yet known how HIV-1 transferred from monkeys to man; suggestions include consumption of monkeys as food, the use of monkey tissues in religious rites or aberrant sexual practices. Whutever, something permitted one or more simian retroviruses to adapt to human beings. Once established in humans, IIIV-1 has been selected for gas- trointestinal and genitourinary tract mucosal infectivity. This has promoted rapid spread through both homosexual and heterosexual intercourse. In many African cultures, plural marriages or tolerated promiscuity have contributed to the heterosexual spread of AIDS. For much of mainland Asia, widespread commercial sex, cultural tolerance of intense promiscuity among young males and, in some cases, grinding poverty have contributed to the propagation of HIV-1 variants, which are spreading with unprecedented speed by the heterosexual route.

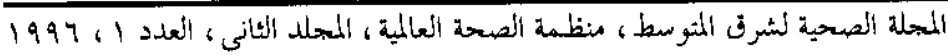


Whatever its mechanism of spread, the biological complexities of HFV-1 and its apparently endless retinue of immunological escape mechanisms have frustrated efforts at finding effective antivirals and vaccines that can stop transmission. In the tenth year of the HIV/AIDS epidemic, human behaviour in the form of safe sex or abstinence is the only available method to control the pandemic.

\section{Cholera in the Americas}

Although there were several global pandemics in the 18th and 19th centuries, until recently, Europe and the Americas had been spared from cholera for over 100 years. The Peruvian scenario may explain why the countries of these regions were so successful. In the early 1980 s, under the mistaken notion that chlorine was a human health hazard, chlorination of much of the country's water supplies were suspended. In part because of the poor economy and the rural terrorism imposed by the Shining Path guerrilla movement, rural people had been flooding into Lima where they settled in satellite slum cities. These were without sanitation or piped water. Once cholera was introduced into Lima by the crew of a Chinese freighter berthed in the port city of Callao in January 1991 , contaminated shellfish consumed raw as ceviche plus an unprecedented breakdown in sanitation contributed to an explosive outbreak of the disease.

\section{Asiatic cholera}

In 1993, a "new" or mutant cholera serovar, 0139, spread rapidly in Bangladesh, producing disease in adults as well as children. Cholera vibrio in Bangladesh is transmitted through contaminated water. While infected humans are the principal source of groundwater contamination, the organism is capable of survival for prolonged periods in water, possibly in blue-green algae, and replicating in fin fish and shellfish. It is well known that primary prevention of cholera can be achieved through chlorination or boiling of drinking water, hand-washing and the proper disposal of faeces.

\section{Bloody diarrhoea/haemolytic uraemia syndrome}

In the late 1980 s and early 1990 s, sporadic outbreaks of sometimes fatal bloody diarrhoea and haemolytic uraemia occurred in the United States. The outbreaks implicated consumption of undercooked hamburgers served at fast food restaurants. Meat received from a central supply was found to be contaminated with the O157:H7 serotype of Escherichia coli. It is one of several enterohaemorrhagic $E$. coli strains that produce potent Shiga-like toxins. Contamination of red or white meats by $E$. coli is an everpresent threat. This rare event can become a big problem when very large lots of foodstuffs are contaminated. Shipment of small lots to a large number of outlets obscures recognition of outbreaks. Prevention and control require thorough inspection of meats and the maintenance of high standards of restaurant hygiene.

\section{Ebola haemorrhagic fever}

This disease is an example of a classic, severe and fearsome nosocomial infection. Inadequately sterilized injection equipment. use of family members to nurse patients and the absence of barrier nursing has been implicated in transmission. Needle sticks or scalpel cuts and the contamination of open cuts with blood or other body fluids are extremely hazardous. The virus may occasionally be spread from person-to-person via the respiratory route. What makes Ebola fever so feared is its very high case fatality rate (80-90\%). Adding to the fear and mystery that surrounds the disease is the obscurity of its origin. Despite outhreaks in 7aire and 
Sudan in the 1970s and again in Zaire in 1995, extensive virological and serological studies of wild and domestic animals in central Africa have failed to identify a reservoir cycle. An antigenically related filovirus, Reston, which produces fatal disease in macaques, may have a maintenance cycle in Philippine monkeys. As has been demonstrated several times, Ebola infections can be prevented by use of disposable syringes and needles and by barrier nursing.

\section{Dengue haemorrhagic fever}

Dengue appears to be an example of an organism in which pathogenicity increases with increased infection of vertebrate hosts. Urban dengue is transmitted in a simple cycle involving Aedes aegypti mosquitoes and man. Every year since the end of the Second World War, dengue viruses have been transmitted to larger and larger populations of human beings. This is because of the end of colonial health services, the disruptions caused by the war itself and, in the Americas, the re-emergence of A aegypti. After the war, the population explosion and the rural-to-urban migration caused city populations to swell enormously. This increased population and the deterioration of many tropical cities provided fertile grounds for A. aegypti to breed, accelerating the transmission of dengue viruses and leading to endemic dengue haemorrhagic fever and dengue shock syndrome.

Dengue is dependant upon human behaviour. A. aegypti breeds in and around human habitations in water storage jars, discarded tins, plastic containers, bottles and rubber tyres, all provided by humans. As has been amply demonstrated by the successful hemispheric mosquito eradication programme of the $1950 \mathrm{~s}$, A. aegypti is very dependent upon man-made containers for breeding.
Although vaccines are being developed at present, only the reduction of mosquito breeding sources can prevent dengue diseases. Source reduction requires individual and collective behaviour changes.

\section{Yellow fever}

Yellow fever is a close virological relative to dengue. Both viruses are transmitted in urban areas by the same vector. Each virus has a sylvan cycle; yellow fever is enzootic in the Amazon basin and throughout west Africa. For over 50 years a fully potent yellow fever vaccine has been available. Wherever yellow fever occurs, always there is failure to vaccinate. This is particularly a problem in poverty-stricken west African countries, which find it difficult to find the resources to purchase and distribute yellow fever vaccine.

In 1995, Peru suffered the largest epidemic of jungle yellow fever in recorded history (Watts, D. Personal communication). Nearly 500 cases occurred, predominantly in coffee plantation workers. Because of the failure of coffee crops elsewhere, late in 1994 and early 1995 Peruvian plantations were expanded. Workers were recruited from Amazonian villages far from the hilly terrain where jungle yellow fever is enzootic. Few, if any of these workers had received yellow fever vaccine.

\section{Drug resistance: malaria, tuberculosis}

Widespread use, and in some instances, abuse of curative or preventive chemotherapeutic drugs can result in the selection of resistant organisms. This kind of emergence phenomenon is by no means restricted to the two diseases mentioned. A disturbingly large number of microorganisms are becoming resistant to antibiotics. In many countries, the promiscuous use of potent antibiotics and chemotherapentic drugs is

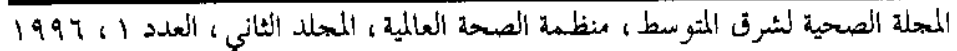


the result of the failure to pass or enforce pharmacy laws. Powerful drugs can often be purchased without a prescription; because of financial constraints sick people often buy one pill at a time. This chronic underdosing is a sure way to select for antibiotic resistance.

\section{Lyme disease}

Lyme disease is caused by a spirochete, Borrelia burgdorferi, which is transmitted by ticks, predominantly the nymphal stages. The Ixodes tick populations are amplified by feeding on large vertebrates, particularly deer. In the United States, the spread of Lyme disease is related to the explosion of deer populations that have followed the reforestation of large areas, particularly in the north-east. One of the most effective means to prevent Lyme disease would be to reduce deer populations. The humans in the affected areas, however, are highly protective of deer, an attitude that has prevented efforts to keep deer populations at the low levels required to reduce Borrelia transmission.

\section{Toxic shock syndrome}

loxic shock syndrome (TSS) is associated with the use of super-absorbent tampons that have been left in the vagina for several days. This provides both a site and medium for growth for Staphylococcus aureus, which under these circumstances may release the toxin that causes toxic shock syndrome. Prevention required tampon redesign.

\section{Discussion}

The emerging disease problems illustrated have been supported or amplified by human factors such as promiscuity; poor sanitation; mass marketing; no barrier nursing; providing mosquito breeding sites, and uncontrolled overuse of antibiotics.

Control of each of the emerging disease problems listed requires individual or collective preventive action. AIDS, cholera, Ebola fever, dengue and toxic shock syndrome can be controlled to some measure by individual actions, while collective government decisions are needed for the prevention

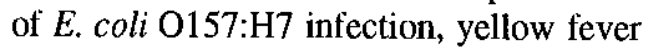
and antibiotic resistance.

A similar analysis of the complete list of emerging infectious diseases should reveat the fact that human factors contribute disproportionately to emergence phenomena; most certainly it is upon human behaviour that rational approaches to prevention and control are based.

\section{Further reading}

\section{AIDS}

Kimball AM, Berkley S, Ngugi E, Gayle H. International aspects of the AIDS/HIV epidemic. Annual reviews of public health, 1995, 16:253-82.

Hantavirus pulmonary syndrome Butler JC, Peters CJ. I lantaviruses and hantavirus pulmonary syndrome. Clinical infectious disease, 1994, 19:387-94.
Cholera, Peru

Anderson C. Cholera epidemic traced to risk miscalculation. Nature, 1991 , 954:255.

Cholera, O139

Kaper JB, Morris JG Jr, Levine MM. Cholera. Oinical microbiology reviews, $1995,8: 48-86$. 
Islam MS et al. Isolation of Vibrio cholerae 0139 synonym Bengal from the aquatic environment in Bangladesh: implications for disease transmission. Applied environmental microbiology, 1994, 60:1684-6.

Epstein PR. Algal blooms in the spread and persistence of cholera. Biosystems, 1993, 31:209-21.

E. coli 0157:H7

CDC. Update: multistate outbreak of Escherichia coli 0157:H7 infections from hamburgers-western United States, 1993. Morbidity and mortality weekly report, 1993, 42:258-63.

\section{Ebola fever}

Outbreak of Ebola viral haemorrhagic fever-Zaire, 1995. Morbidity and mortality wookly report, 1995, 44:381-2.

Dengue haemorrhagic fever

Halstead SB. Pathogenesis of dengue: challenges to molecular biology. Science, 1988, 239:476-81.

Halstead SB. The twentieth century dengue pandemic: Need for survoillance and research. World health statistical quarterly, 1992, 45:292-8.

Yellow fover

Monath TP. Yellow fever-a medically neglected disease. Reviews of infectious diseases, 1987, 9:165-75.
Drug resistance

Cohen ML. Epidemiology of drug resistance: implications for a postantimicrobial era, Science, 1992, 257:1050-5.

Aitt Valley fever

Wilson ML. Rift Valley fever virus ecology and the epidemiology of disease emergence. Annals of the NY Academy of Science, 1994, 740:169-80.

Arthur RR et al. Recurrence of Rift Valley fever in Egypt. Lancet, 1993, 342:1149-50.

\section{Lyme disease}

Steere AC. Lyme disease. New England journal of medicine, 1989, 321:586-96.

\section{Toxic shock syndrome}

Davis JP et al. Toxic shock syndrome: epidemiological features, recurrence, risk factors and prevention. New England journal of medicine, 1980, 303:1429-35.

Todd JK. Toxic shock syndrome. Clinical microbiology reviews, 1988, 1:432-46, 1988.

\section{General}

Epstein PR. Emerging diseases and ecosystem instability: new threats to public health. American journal of public health, 1995, 85:168-72. 